\title{
Analysis of the Placental Tissue Transcriptome of Normal and Preeclampsia Complicated Pregnancies
}

\author{
E. A. Trifonova ${ }^{1,5}$, T. V. Gabidulina ${ }^{2}$, N. I. Ershov ${ }^{3}$, V. N. Serebrova ${ }^{1}$, A. Yu. Vorozhishcheva ${ }^{4}$, \\ V. A. Stepanov ${ }^{1,5^{*}}$ \\ ${ }^{1}$ Research Institute of Medical Genetics, Siberian Branch, Russian Academy of Medical Sciences, \\ Nab. Ushayky 10, 634050, Tomsk, Russia \\ ${ }^{2}$ Siberian State Medical University, Ministry of Health of the Russian Federation, Moskovsky Trakt, \\ 2, 634050, Tomsk, Russia \\ ${ }^{3}$ Institute of Cytology and Genetics, Siberian Branch, Russian Academy of Sciences, Prosp. \\ Lavrentieva 10, 630090, Novosibirsk, Russia \\ ${ }^{4}$ City Clinical Hospital № 1, Ul. Khitarova, 32, 654000, Novokuznetsk, Russia \\ ${ }^{5}$ Tomsk State University, Lenina Avenue, 36, 634050, Tomsk, Russia \\ *E-mail: vadim.stepanov@medgenetics.ru \\ Received 28.08.2013 \\ Revised manuscript received 23.12.2013 \\ Copyright @ 2014 Park-media, Ltd. This is an open access article distributed under the Creative Commons Attribution License, which permits \\ unrestricted use, distribution, and reproduction in any medium, provided the original work is properly cited.
}

ABSTRACT Preeclampsia is one of the most severe gestational complications which is one of the leading cause of maternal and perinatal morbidity and mortality. A growth in the incidence of severe and combined forms of the pathology has been observed in recent years. According to modern concepts, inadequate cytotrophoblast invasion into the spiral arteries of the uterus and development of the ischemia-reperfusion syndrome in the placental tissue play the leading role in the development of preeclampsia, which is characterized by multipleorgan failure. In this regard, our work was aimed at studying the patterns of placental tissue transcriptome that are specific to females with $\mathrm{PE}$ and with physiological pregnancy, as well as identifying the potential promising biomarkers and molecular mechanisms of this pathology. We have identified 63 genes whose expression proved to differ significantly in the placental tissue of females with PE and with physiological pregnancy. A cluster of differentially expressed genes (DEG) whose expression level is increased in patients with preeclampsia includes not only the known candidate genes that have been identified in many other genome-wide studies (e.g., $L E P$, BHLHB2, SIGLEC6, RDH13, BCL6), but also new genes ( $A N K R D 37, S Y D E 1, C Y B A, I T G B 2$, etc.), which can be considered as new biological markers of preeclampsia and are of further interest. The results of a functional annotation of DEG show that the development of preeclampsia may be related to a stress response, immune processes, the regulation of cell-cell interactions, intracellular signaling cascades, etc. In addition, the features of the differential gene expression depending on preeclampsia severity were revealed. We have found evidence of the important role of the molecular mechanisms responsible for the failure of immunological tolerance and initiation of the pro-inflammatory cascade in the development of severe preeclampsia. The results obtained elaborate the concept of the pathophysiology of preeclampsia and contain the information necessary to work out measures for targeted therapy of this disease.

KEYWORDS microarrays; placenta; genome-wide analysis; preeclampsia; transcriptome; gene expression. ABBREVIATIONS DEG - differentially expressed genes; MFDs - multifactorial diseases; PE - preeclampsia; GWAS - genome-wide association study; SNP - single nucleotide polymorphism.

\section{INTRODUCTION}

The numerous genome-wide association studies (GWAS) conducted so far have provided valuable information on the genetic architecture of multifactorial diseases (MFDs) and revealed hundreds of the risk alleles of single-nucleotide polymorphisms (SNPs) associated with many phenotypes. However, they explain only a relatively small part of the inheritance of complex traits and have only a very mild impact on the phenotype of associated variants [1]. These results raise the missing heritability problem, which is being intensively discussed today. Another limitation of the GWAS effectiveness related to studies of the hereditary component of predisposition to MFDs is associated with the use of tagSNP. The risk alleles identified in GWAS typically do not belong to the "causal" ones, but are in linkage 
disequilibrium (LD) with functionally significant variant alleles [2]; therefore, the biological interpretation of GWAS results is a serious problem.

The current approaches to the identification of the "causal" allelic variants linked to the polymorphisms detected in GWAS are based on the analysis of the coding or transcribed genomic regions [2-4]. However, the vast majority of SNPs identified in GWAS are located in the non-transcribed regions. They are not linked to variants located in exons, and the mechanism of their action is apparently associated with the regulation of gene expression [5, 6]. Therefore, post-genomic methods (which readily provide information on almost all the components coordinating the basic functions of genes, RNA, and proteins at different hierarchical levels) become especially relevant in studying the genetic architecture and molecular mechanisms of MFDs. One such approach, namely the high-performance measurement of gene expression using microarray technology, was used in the present work to characterize the transcriptome patterns in normal pregnancy and preeclampsia $(\mathrm{PE})$, one of the most severe gestational complications.

Preeclampsia, which is associated with the multiple organ dysfunction syndrome, is a specific syndrome that occurs after the $20^{\text {th }}$ week of pregnancy and is characterized by hypertension and proteinuria. $\mathrm{PE}$ is diagnosed in $70 \%$ of hypertensive disorders in pregnancy, and an increase in the incidence rate of severe and combined forms of this disease has been observed in recent years [7]. Despite the large number of theories related to etiopathogenesis (neurogenic, hormonal, placental, immunological, genetic, etc.), numerous studies of the mechanisms of development of this disease, and the emergence of new therapies, $\mathrm{PE}$ remains a leading cause of maternal and perinatal morbidity and mortality. The disease is responsible for up to $70 \%$ of stillbirths and miscarriages; the risk of perinatal losses increases almost fivefold in $\mathrm{PE}[7,8]$.

According to the modern concepts, the etiopathogenesis of preeclampsia is closely related to inadequate cytotrophoblast invasion in the uterine spiral arteries and development of the ischemia-reperfusion syndrome, which induces oxidative stress and systemic inflammation $[9,10]$. Etiological factors and the mechanisms of this disorder remain unclear and require close attention. In order to identify the likely candidate biomarkers of PE and to study the molecular mechanisms of gestational complications, we analyzed the patterns of the placental transcriptome that are specific to $\mathrm{PE}$ and physiological pregnancy, since the placental tissue obviously plays the key role in the development of $\mathrm{PE}$. The strategy of using microarrays in this context seems to be reasonable and powerful enough, as it allows one to thoroughly investigate the possible changes in gene expression associated with the pathophysiology of preeclampsia at the transcriptome level.

\section{EXPERIMENTAL}

Characteristics of the examined groups

A total of 10 patients with $\mathrm{PE}$ and 11 patients with physiological pregnancy (the control group) were examined (Table 1). The questionnaire included demographic information (ethnicity) and anthropometric parameters (height, weight), lifestyle (smoking habit, psychoactive substance abuse), as well as information about the somatic and obstetric-gynecological history. $\mathrm{PE}$ was diagnosed based on leading clinical symptoms of various severity, such as proteinuria, edema, hypertension (systolic blood pressure above $140 \mathrm{~mm} \mathrm{Hg}$, diastolic blood pressure above $90 \mathrm{~mm} \mathrm{Hg}$ ) according to the $10^{\text {th }}$ revision of the International Classification of Diseases. PE severity was evaluated according to the criteria of the clinical protocol 2012 "Hypertension during Pregnancy. Preeclampsia. Eclampsia" [11].

The group of PE patients was heterogeneous both in terms of severity (the study included six patients with moderate and four patients with severe PE) and the presence of prior diseases and comorbidities. Four patients were diagnosed with $\mathrm{PE}$ in the absence of background diseases; in others the gestational complications developed against the backdrop of extragenital diseases including hypo-/hypertensive type neurocirculatory dystonia, chronic pyelonephritis, chronic cholecystitis, and chronic arterial hypertension. Six females in the control group were also diagnosed with both chronic pyelonephritis and chronic cholecystitis. The age of the gravidas ranged from 18 to 33 years in both groups; the groups were comparable in terms of the average age. Statistically significant differences in the height and weight of infants between the control group and the group of patients were found. The groups also differed in terms of arterial blood pressure and time of birth.

\section{Collection of placental samples}

We examined the distal (maternal) portion of the placenta. The tissues were sampled immediately after delivery (sample ischemia time did not exceed $10 \mathrm{~min}$ ). Placental tissue samples were taken from the central areas close to the umbilical cord at a placental depth of $0.5 \mathrm{~cm}$. The samples were collected from macroscopically normal sections of the placenta (without hemorrhage, calcification, necrosis, or fibrin deposition) without intervening large vessels, washed with saline to remove the residual maternal blood and amniotic fluid, immediately immersed in RNAlater (Ambion, UK), and transferred to be stored at $-80^{\circ} \mathrm{C}$ until the RNA iso- 
Table 1. Characteristics of the examined groups

\begin{tabular}{|c|c|c|c|}
\hline Parameters & $\mathrm{PE}, N=10$ & $\begin{array}{c}\text { Control group, } \\
\quad N=11\end{array}$ & p-value* \\
\hline Mean age, years & $26 \pm 2$ & $28 \pm 3$ & 0.241 \\
\hline Mean weight, kg & $60 \pm 7$ & $62 \pm 6$ & 0.324 \\
\hline Body mass index, BMI & $23 \pm 4$ & $23 \pm 3$ & 0.832 \\
\hline The mean maximum systolic blood pressure, $\mathrm{mm} \mathrm{Hg}$ & $162 \pm 19$ & $121 \pm 3$ & 0.0001 \\
\hline The mean maximum diastolic blood pressure, $\mathrm{mm} \mathrm{Hg}$ & $104 \pm 13$ & $80 \pm 4$ & 0.0001 \\
\hline Delivery time, weeks & $38 \pm 1$ & $40 \pm 2$ & 0.009 \\
\hline Birth weight, g & $2783 \pm 560$ & $3549 \pm 345$ & 0.004 \\
\hline Length at birth, cm & $50 \pm 4$ & $53 \pm 2$ & 0.021 \\
\hline Premature birth, $\%$ & 50 & 0 & 0.012 \\
\hline Chronic diseases, \% & 60 & 50 & 0.575 \\
\hline
\end{tabular}

* The significance level was determined by comparing the groups using the Mann-Whitney test or Fisher's exact test.

lation procedure. A histological examination revealed chorionic villi and decidua tissue with fibrinoid necrosis foci and small calcifications in all biopsy specimens (Fig. 1).

\section{RNA Isolation}

Tissue samples (100-200 mg) were homogenized using TissueLyser (Qiagen) in Trizol; RNA was then isolated using the standard protocol. The concentration of total RNA was determined using Nanodrop ND-1000 based on absorbance at $260 \mathrm{~nm}$ in water. The quality of the samples was monitored using an Agilent 2100 Bioanalyzer capillary electrophoresis system (Agilent Technologies Inc., Palo Alto, USA) and spectrophotometric scanning.

\section{Microarray analysis}

A genome-wide profile of gene expression in the placental tissue was determined using hybridization on HT-12 BeadChip microarrays (Illumina, USA) containing information about more than 48,000 transcripts. After hybridization, the microarrays were scanned on an Illumina BeadArray Reader device. The raw data were converted into mean values of the signal intensity for each sample (Sample Probe Profile) using the BeadStudio v3 software package (Illumina).

\section{Bioinformatic analysis}

The data were analyzed in an $\mathrm{R}$ software environment using the limma program package [12]. Nonparametric background correction followed by quantile normalization (neqc function) was performed for the entire data set. The specimens that were identified in all the sam-

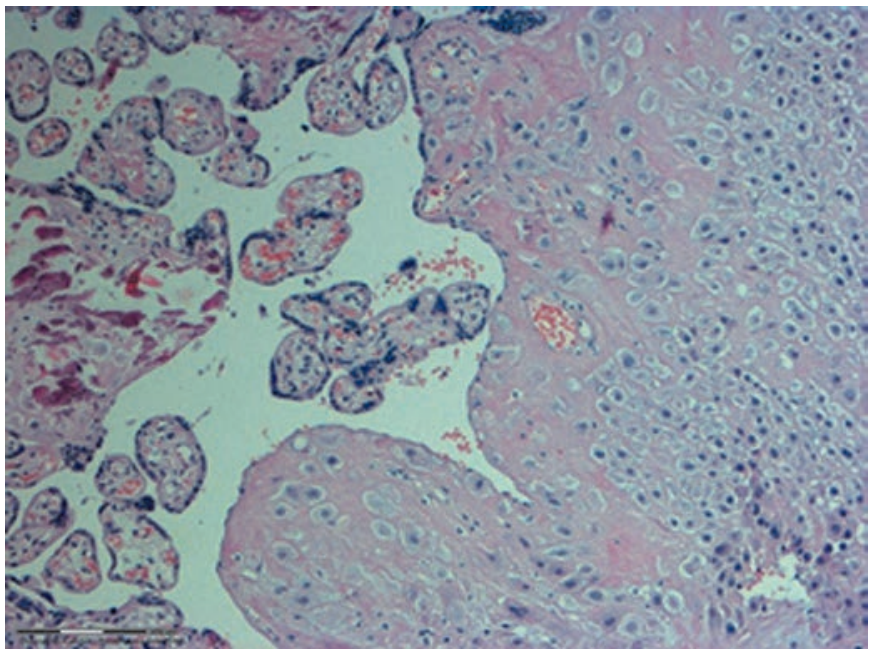

Fig. 1. Micrograph of one of the studied placental biopsy samples. Hematoxylin- and eosin-stained

ples of at least one of the experimental groups (detection $\mathrm{p}$-value $<0.01$ ) were further considered. A differential expression analysis was performed using multiple linear regression and moderated t-statistics [12], including the assessment of the quality weights of microarray reading [13] and Benjamin-Hochberg multiple testing correction (FDR) procedure. A 1.5-fold (or greater) change in the level of gene expression (FC - fold change) was considered to be significant at the adjusted significance level of $p \leq 0.1$. Functional annotation and functional cluster analysis of the groups of differentially expressed genes (DEGs) were performed using the DAVID (Database 


\begin{tabular}{|c|c|c|c|c|c|c|c|}
\hline 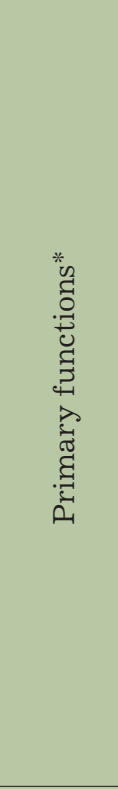 & 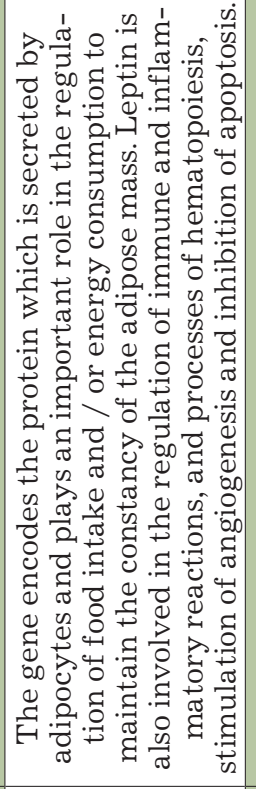 & 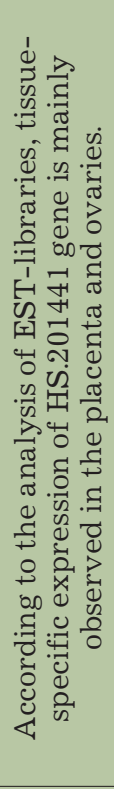 & 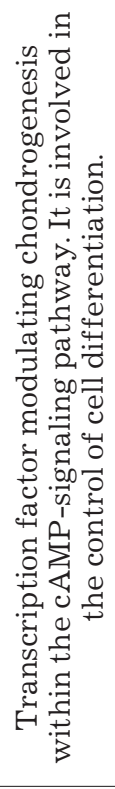 & 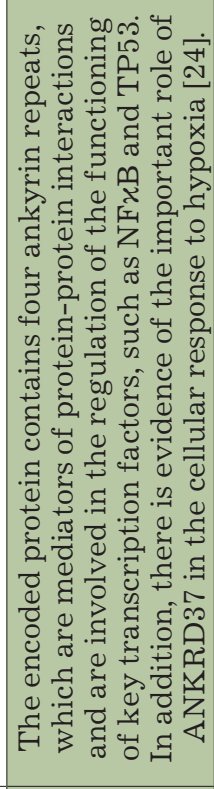 & 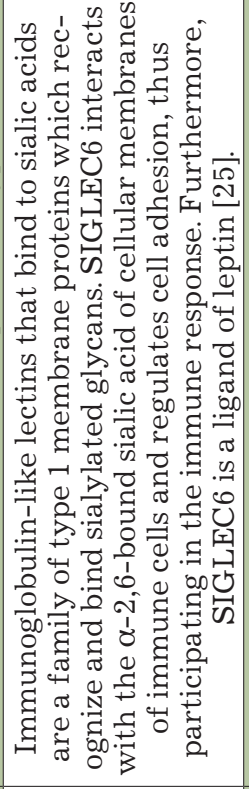 & 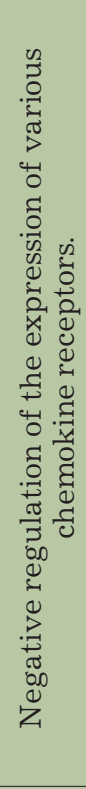 & 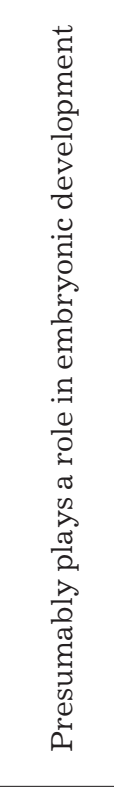 \\
\hline 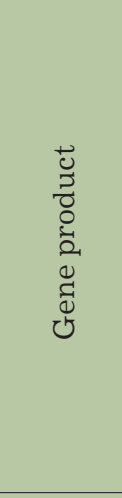 & 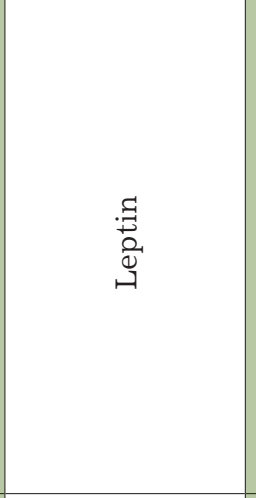 & 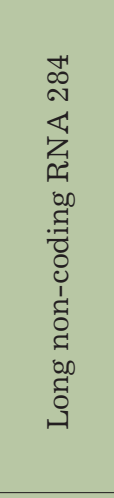 & 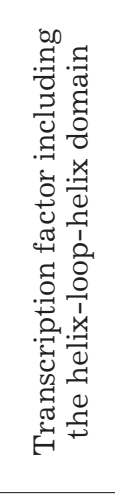 & 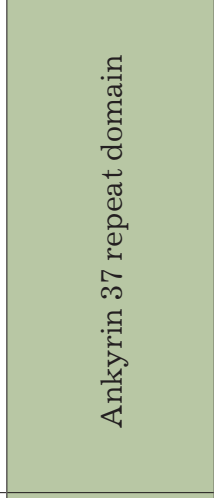 & 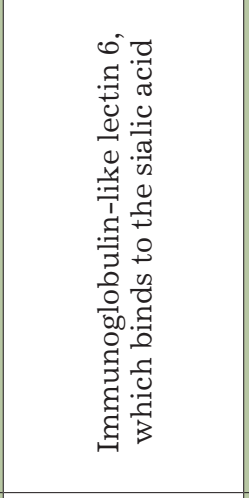 & 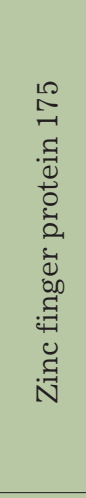 & 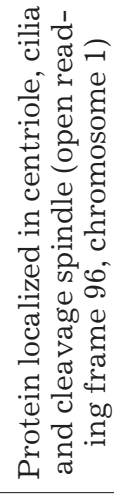 \\
\hline 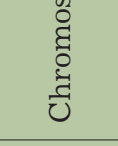 & $\sim$ & $\stackrel{\infty}{\rightarrow}$ & $\infty$ & $r$ & $\stackrel{\rho}{\rightarrow}$ & $\stackrel{\rho}{\rightarrow}$ & $\neg$ \\
\hline 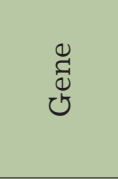 & 国 & 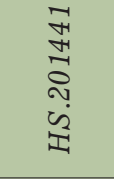 & 勇 & 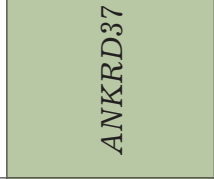 & 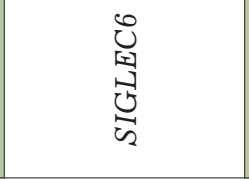 & 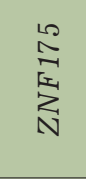 & 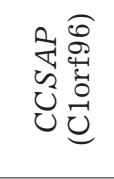 \\
\hline 公 & $\begin{array}{l}0 \\
\stackrel{\circ}{0} \\
\circ\end{array}$ & $\begin{array}{l}\overrightarrow{8} \\
\text { Oे }\end{array}$ & $\begin{array}{l}\stackrel{8}{0} \\
\stackrel{0}{0} \\
0\end{array}$ & $\begin{array}{l}\overrightarrow{0} \\
\stackrel{0}{0} \\
\dot{0}\end{array}$ & $\begin{array}{l}0 \\
\dot{0} \\
0 \\
0\end{array}$ & $\begin{array}{l}\mathscr{8} \\
\stackrel{8}{0} \\
\stackrel{0}{0}\end{array}$ & $\begin{array}{l}\overrightarrow{\tilde{O}} \\
\stackrel{0}{0} \\
\dot{0}\end{array}$ \\
\hline$\bigcup_{I_{1}}$ & $\begin{array}{l}\stackrel{H}{0} \\
\stackrel{\leftrightarrow}{0} \\
\stackrel{-}{*}\end{array}$ & 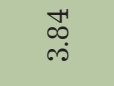 & 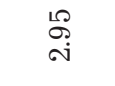 & 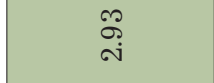 & $\vec{\sigma}$ & $\begin{array}{l}\text { H. } \\
\text { i }\end{array}$ & $\stackrel{\infty}{\stackrel{\leftrightarrow}{\leftrightarrow}}$ \\
\hline 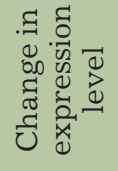 & $\leftarrow$ & $\rightarrow$ & $\leftarrow$ & $\leftarrow$ & $\leftarrow$ & $\leftarrow$ & $\leftarrow$ \\
\hline$\stackrel{011}{r}$ & $\rightarrow$ & N & $\infty$ & $H$ & 10 & 0 & $\sim$ \\
\hline
\end{tabular}




\begin{tabular}{|c|c|c|c|c|c|c|c|}
\hline 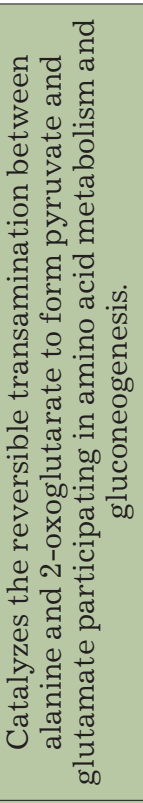 & 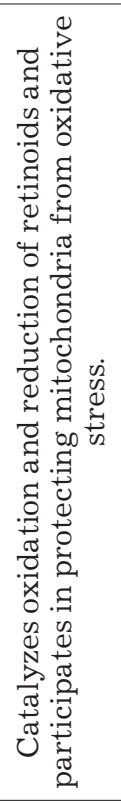 & 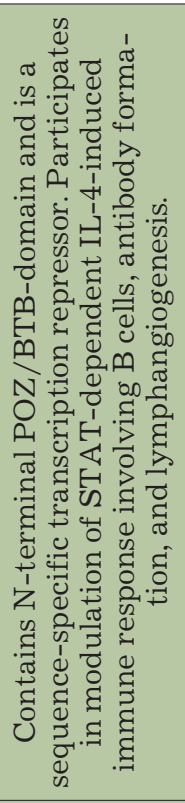 & 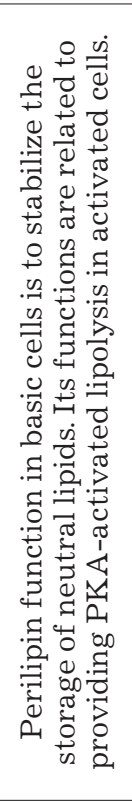 & 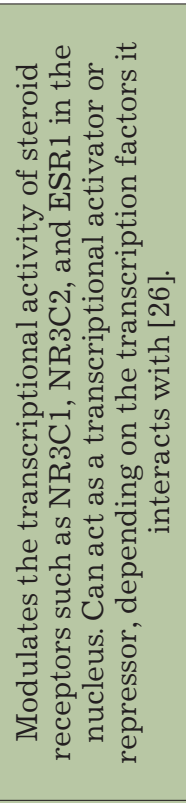 & 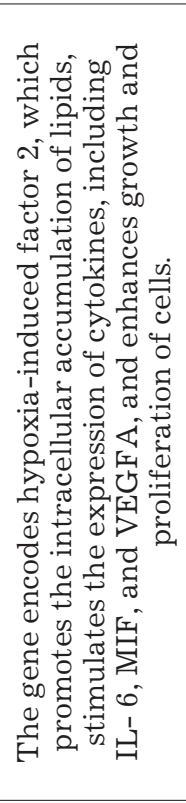 & 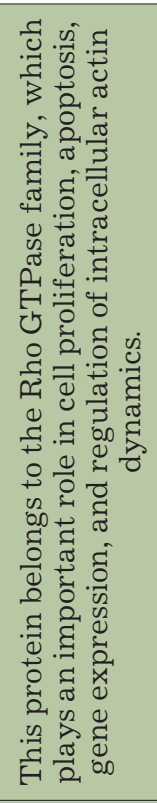 & 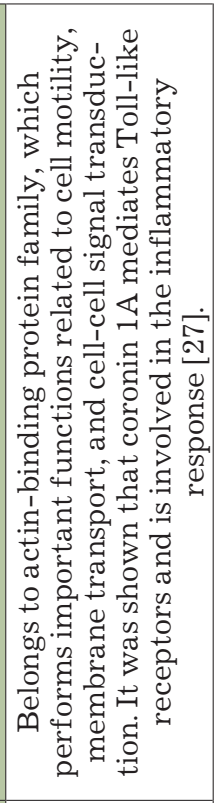 \\
\hline 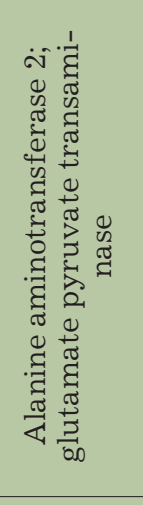 & 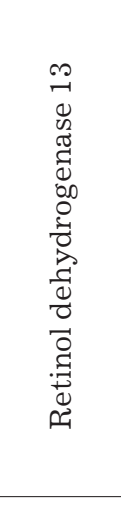 & 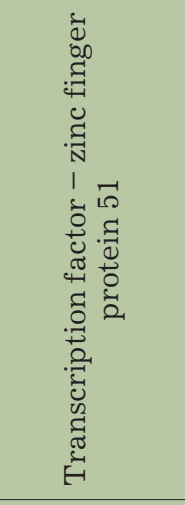 & 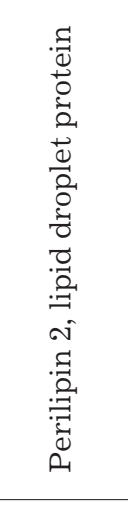 & 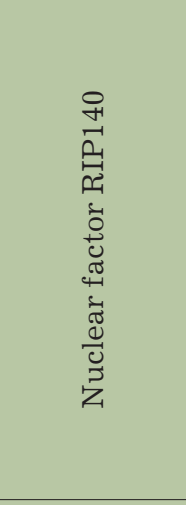 & 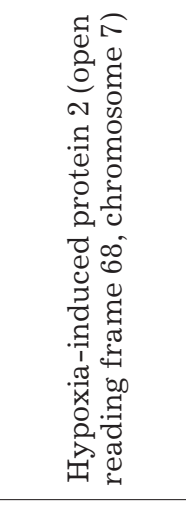 & 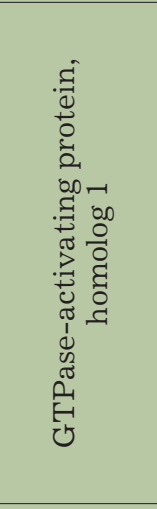 & 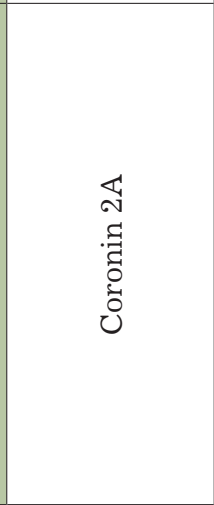 \\
\hline$\stackrel{\bullet}{\bullet}$ & $\stackrel{\rightarrow}{\sim}$ & $\infty$ & $\sigma$ & $\overrightarrow{\mathrm{N}}$ & $\sim$ & $\stackrel{\oplus}{\rightarrow}$ & $\sigma$ \\
\hline 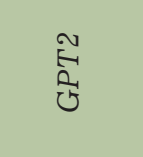 & 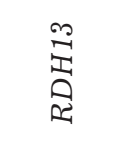 & 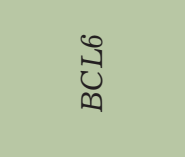 & 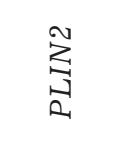 & $\begin{array}{l}\vec{Z} \\
\overrightarrow{0 L} \\
z\end{array}$ & 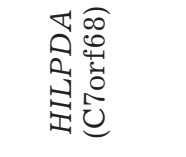 & 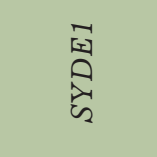 & 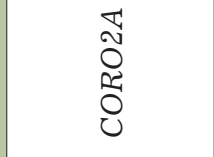 \\
\hline $\begin{array}{l}\text { 요 } \\
\stackrel{8}{0} \\
0\end{array}$ & $\begin{array}{l}\stackrel{0}{1} \\
\stackrel{8}{8} \\
0 \\
0\end{array}$ & $\begin{array}{l}\stackrel{8}{0} \\
8 \\
0 \\
0\end{array}$ & $\begin{array}{l}0 \\
\stackrel{8}{8} \\
0 \\
0\end{array}$ & $\begin{array}{l}\stackrel{+}{\mathrm{N}} \\
\stackrel{0}{0} \\
0\end{array}$ & $\begin{array}{l}\text { ô } \\
\text { ț } \\
0\end{array}$ & $\begin{array}{l}0 \\
8 \\
0 \\
0 \\
0\end{array}$ & $\begin{array}{l}0 \\
\stackrel{8}{8} \\
0 \\
0\end{array}$ \\
\hline$\stackrel{\Re}{\stackrel{\leftrightarrow}{N}}$ & 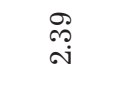 & 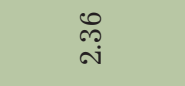 & 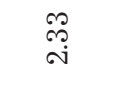 & $\overrightarrow{\widetilde{N}}$ & $\stackrel{\infty}{\vec{S}}$ & $\stackrel{\infty}{\overrightarrow{\mathrm{N}}}$ & $\underset{\text { : }}{\stackrel{\circ}{0}}$ \\
\hline$\leftarrow$ & $\leftarrow$ & $\leftarrow$ & $\leftarrow$ & $\leftarrow$ & $\leftarrow$ & $\leftarrow$ & $\leftarrow$ \\
\hline$\infty$ & $\sigma$ & $\stackrel{ }{-1}$ & $\Rightarrow$ & $\stackrel{ }{\ni}$ & $\stackrel{\oplus}{-}$ & $\underset{-}{\stackrel{H}{\prime}}$ & $\stackrel{\Omega}{\sim}$ \\
\hline
\end{tabular}



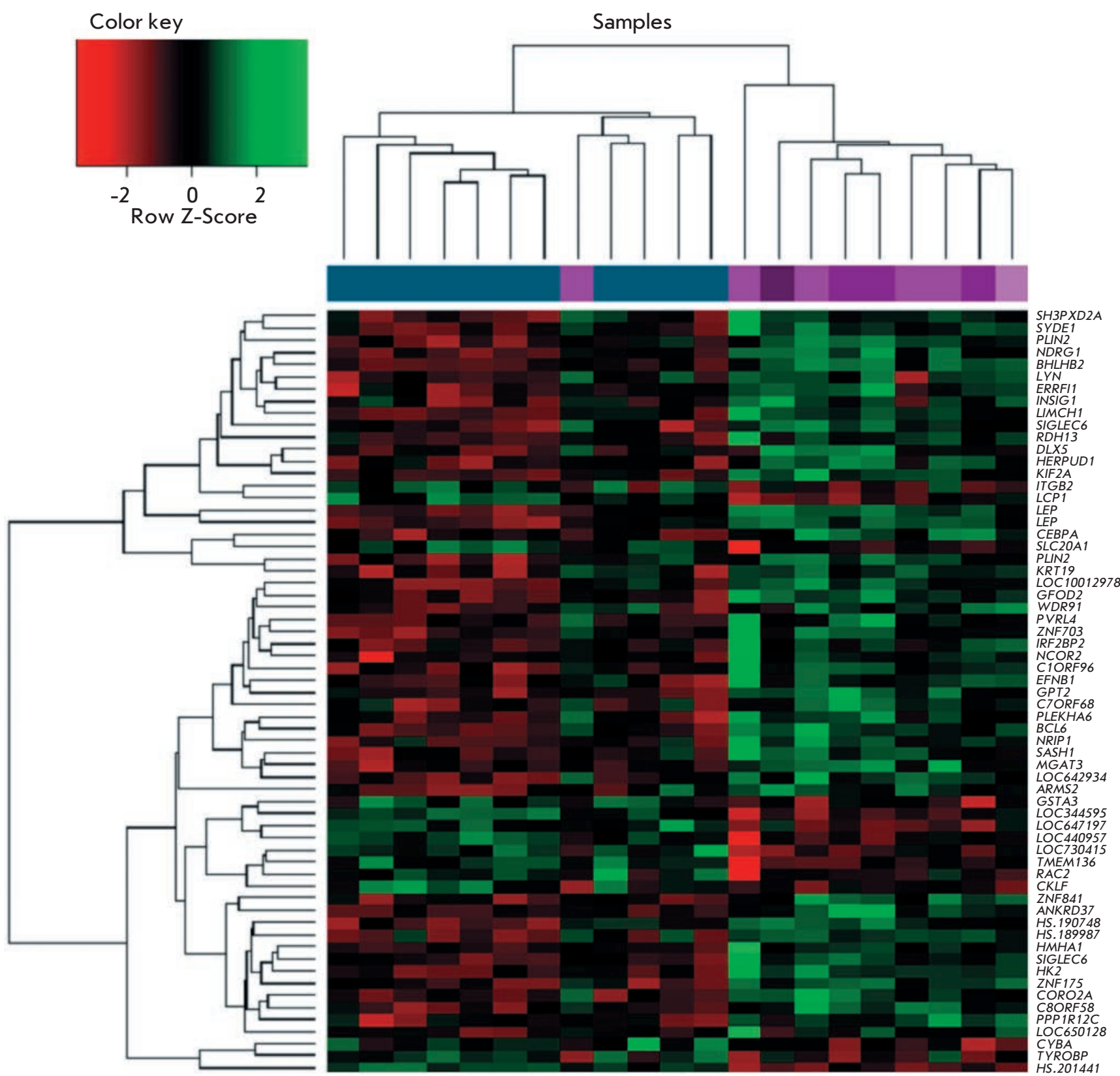

Fig. 2. Heatmap of DEGs (FDR $<0.1 ; F C \leq 1.5$ ). Each column represents a sample; each row represents DEG. Samples from PE patients are shown in pink; samples from the females of the control group are shown in blue. The color scale of the heatmap indicates the deviation of the normalized expression level in the cell from the mean value for the row

for Annotation, Visualization and Integrated Discovery) web-based tool with the standard values of clustering parameters and enrichment score EASE $\leq 0.01[14]$. Construction of gene networks was performed using the STRING 9.0 program (Search Tool for the Retrieval of Interacting Genes) [15].

This study was approved by the Ethics Committee at the Research Institute of Medical Genetics, Siberian Branch of the Russian Academy of Medical Sciences.

\section{RESULTS}

Our analysis identified 63 genes with significantly different expressions (FDR $<0.1 ; \mathrm{FC} \geq 1.5$ ) in the placental tissue of females with $\mathrm{PE}$ and physiological pregnancy (50 DEGs with an increased expression level and 13 DEGs with a decreased expression level). The DEG cluster, whose expression was increased in PE, includes not only known candidate genes that have previously been identified in many genome-wide studies of the ex- 


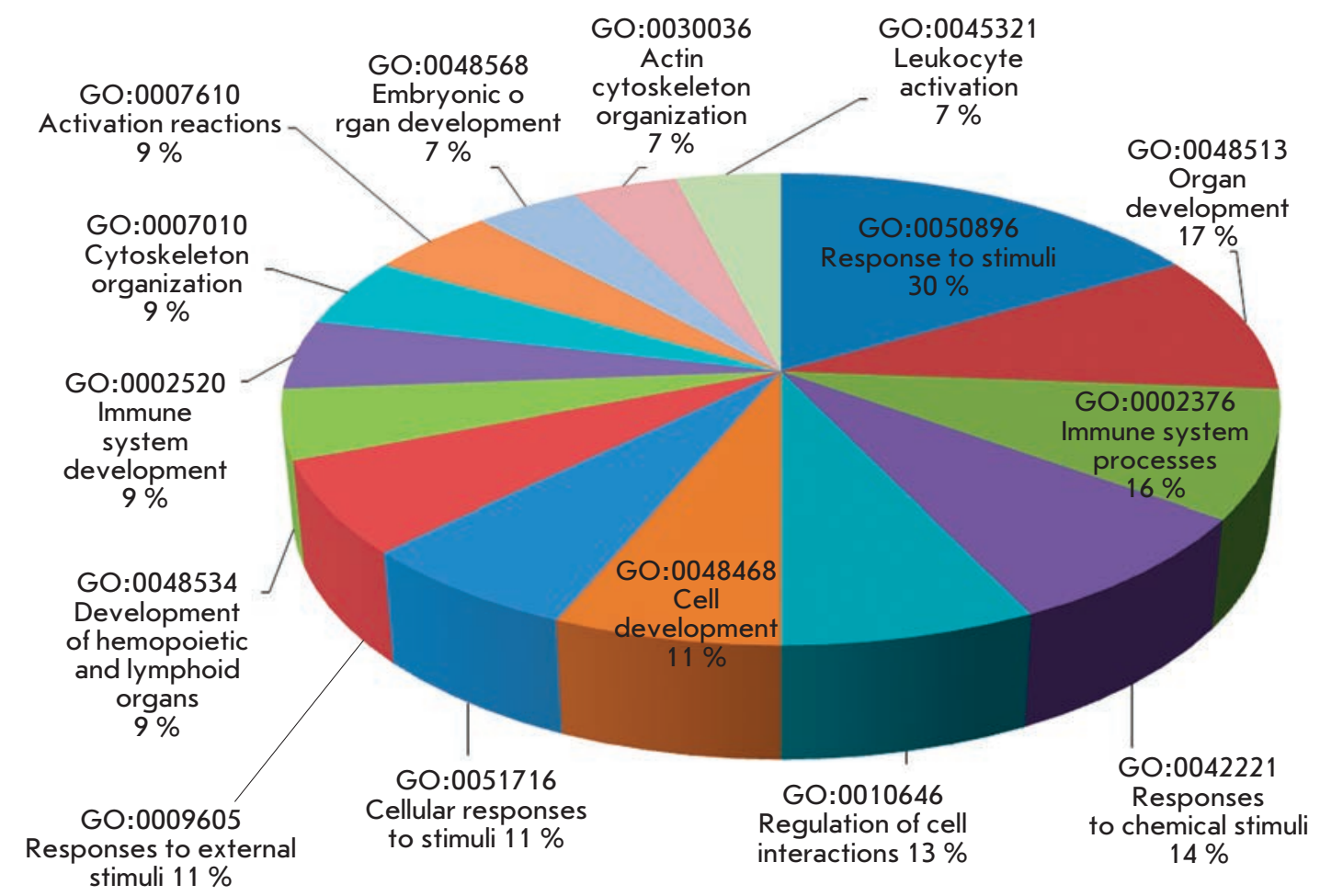

Fig. 3. Main

biological proc-

esses involving

DEGs, which are

associated with

preeclampsia

$(p<0.05)$. The

percentage

indicates the

proportion of

identified DEGs

associated with

this process

pression profiles of the placental genes in preeclampsia (e.g., LEP, BHLHB2, SIGLEC6, RDH13, BCL6), but also new potential candidate genes (CORO2A, $S Y D E 1$, PLIN2, CEBPA, HK2, NDRG1, ERRFI1, EFNB1, GFOD2, NCOR2, HMHA1, HERPUD1, KIF2A), whose association with the development of $\mathrm{PE}$ has been established either in a few studies [16-21], or was done so for the first time in our work. The products of some of these genes, based on current knowledge on their functional features, can be involved in the etiopathogenesis of $\mathrm{PE}$.

Figure 2 shows the heat map with the results of a hierarchical clustering of females according to the expression level of $63 \mathrm{DEGs}$. It can be seen that all PE patients but one fall into one cluster, while females with physiological pregnancy fall into the other one. One PE sample was assigned to the control group probably due to the significant interindividual variability of the transcription levels of the placental tissue genes. A similar phenomenon was observed in several human cell lines: in particular, in the cell lines of the hepatocyte transcriptome [22, 23].

Table 2 shows the data related to the most significant DEGs (FC $>2, F D R<0.01$ ). The presence of several genes whose products are involved in the transcriptional regulation (BHLHB2, ZNF175, ANKRD37, BCL6) in this list, as well as a significant increase in the expression level of the LEP gene and its receptor gene SIGLEC6 during the development of $\mathrm{PE}$, is of special interest.
We analyzed DEG using the DAVID online resource to study the biological processes associated with the development of PE (Fig. 3). The major categories of molecular functions of the protein products of these genes include responding to various stimuli, immune processes, regulation of cell communication, intracellular signaling cascades, etc. The analysis of metabolic pathways including DEGs has shown that cytotoxicity pathways associated with NK-cells, transendothelial migration of leukocytes, and signaling pathways mediated by GTPase activators are probably involved in the molecular mechanisms of PE.

Protein-protein interactions of DEG products were analyzed to identify the possible relationships with DEGs (Fig. 4). The associations in the constructed network are mainly based on "text mining" (mentioned in the abstract of one article). The coexpression cluster that includes the RAC2, CYBA, TYROBP, HMHA1, ITGB2, $L Y N$ and $L C P 1$ genes should be mentioned. In addition, LEP and its receptor SIGLEC6 and ephrin with its kinase LYN are of certain interest.

Our study also revealed features of differential gene expression depending on PE severity (Table 3). A total of eight DEGs were identified (FDR $<0.1 ; \mathrm{FC} \leq 1.5$ ), whose expression levels were significantly different in moderate and severe forms of the disease. In our opinion, HSPA1A encoding the highly conserved heat shock protein 70 (HSP70) and BAG3 encoding Bis, a Bcl-2 
Fig. 4. Protein-protein interactions between DEG products. The proteins are shown as circles; the color line between these circles indicates the evidential category of protein-protein interaction: yellow literature data ("text mining"), black -according to the analysis of gene coexpression, purple the experimental results, blue - evidence from the databases, pink - cumulative evidence

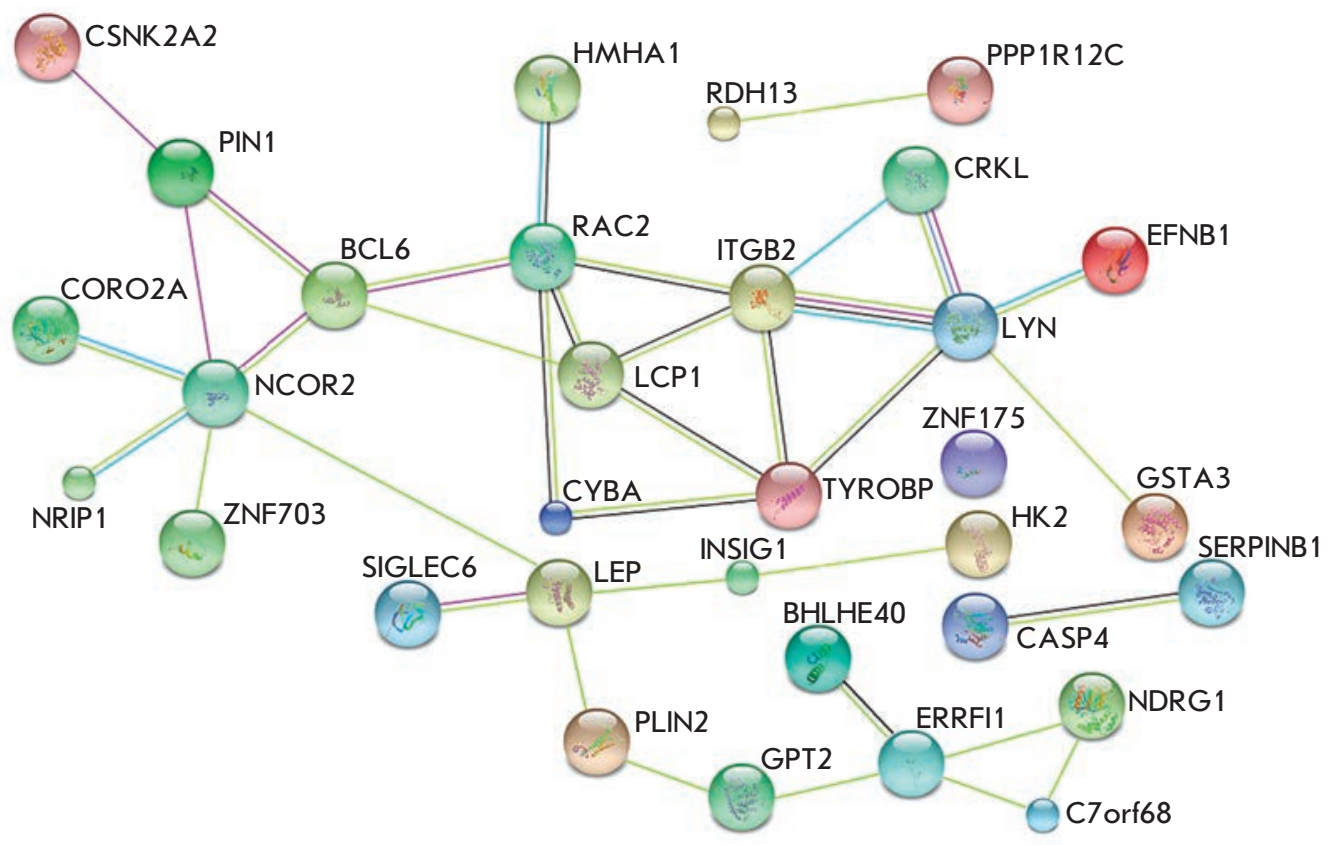

Table 3. List of differentially expressed genes (FDR $<0.1 ; F C \leq 1.5$ ) in moderate to severe preeclampsia

\begin{tabular}{|c|c|c|c|c|}
\hline Gene & $\begin{array}{c}\text { Change in gene } \\
\text { expression level }\end{array}$ & FC & FDR & Gene product \\
\hline HSPA1A & $\uparrow$ & 6.44 & 0.079549 & Heat shock protein 70, HSP70-1A \\
\hline BAG3 & $\uparrow$ & 2.14 & 0.073131 & Bcl-2-associated athanogene 3 \\
\hline SNHG8 & $\uparrow$ & 1.78 & 0.04105 & Small nucleolar RNA 8 \\
\hline LOC729660 & $\downarrow$ & 2.63 & 0.010437 & No data \\
\hline LOC728457 & $\downarrow$ & 2.43 & 0.010437 & No data \\
\hline APOC1 & $\downarrow$ & 2.28 & 0.04433 & Apolipoprotein C1 \\
\hline LOC401357 & $\downarrow$ & 2.27 & 0.010399 & No data \\
\hline LOC 100128326 & $\downarrow$ & 1.92 & 0.079549 & Nota \\
\hline
\end{tabular}

binding protein, are of the greatest interest. The main function of the Bis protein is inhibiting the chaperone activity of the HSP70/HSC70 complex.

A comparative analysis of gene expression profiles in the placental tissue of females with moderate $\mathrm{PE}$ and in the control group revealed 56 transcripts of 52 genes, whose transcription levels differ significantly in these populations. Changes in the expression profile were more pronounced in severe PE: a significant increase in the expression of 55 genes and a decrease in the expression of 35 genes compared to physiological pregnancy were observed (Fig. 5). It should be noted that, along with a small amount of common genes ( 21 genes) that were differentially expressed in both severe and moderate $\mathrm{PE}$, more than $60 \mathrm{DEG}$ s were specific only to the severe form of the pathology. The results of a functional annotation of these genes in the DAVID web-resource point to a number of biological processes that are statistically significantly associated with the development of severe $\mathrm{PE}$, such as processing and presentation of peptide or polysaccharide antigens and protein folding (Table 4). An analysis of the metabolic pathways that involve these genes also demonstrates the important role of the mechanisms of processing and presentation of antigens in the molecular pathogenesis of severe $\mathrm{PE}$ (according to the KEGG and BIOCARTA databases).

\section{DISCUSSION}

The placenta is the key in understanding the physiological processes associated with pregnancy. It is im- 
Table 4. Main biological processes that involve differentially expressed genes characteristic of severe preeclampsia

\begin{tabular}{|c|c|c|}
\hline Categories of biological processes & Gene \\
\hline $\begin{array}{c}\text { Processing and presentation of peptides or polysaccharide } \\
\text { antigens via class II MHC molecules (GO:0002504) }\end{array}$ & HLA-DPA1, CD74, HLA-DMA, HLA-DRA & 0.0421 \\
\hline $\begin{array}{c}\text { Processing and presentation of exogenous peptide } \\
\text { antigens (GO:0002478) }\end{array}$ & HLA-DMA, CD74, HLA-DRA \\
\hline Chaperone-mediated protein folding (GO:0051085) & ERO1L, HLA-DMA, CD74 \\
\hline De novo post-translational protein folding (GO:0051084) & ERO1L, HLA-DMA, CD74 & 0.0467 \\
\hline Reactions of unfolded protein molecules (GO:0006986) & ERO1L, HSPH1,HSPA1A, HERPUD1 & 0.0478 \\
\hline
\end{tabular}

* Significance level including Benjamin-Hochberg multiple testing correction, which characterized the accuracy of the assignment of this set of genes to a certain biological process.

portant to characterize the genes essential for placental function to understand the mechanisms underlying normal and pathological gestation. The results of this work show that the identified DEGs belong to several biological processes associated with immune responses, cell-cell interactions, and responses to various stimuli. It should be noted that the analysis performed using the module for functional annotation clustering of the DAVID bioinformatical resource made it possible to identify 16 clusters. However, only one of them had an enrichment score of over 2. This cluster includes five genes (KRT19, RAC2, LIMCH1, BCL6, LCP1) involved in the biological processes related to the organization of the actin cytoskeleton (GO: 0030036; GO: 0030029; GO: 0007010). Studying the functional role of the actin cytoskeleton is one of the important trends in the study of cellular signaling mechanisms. Numerous experimental data published over the past few years provide evidence of the fact that actin is involved in the regulation of gene expression and mediates it by participating in transcription elongation, assembly of the preinitiation complex, mRNA maturation and export, chromatin reorganization, and other processes [28, 29]. In this context, the increase in the expression level of the CORO2A gene seems interesting. The product of this gene, coronin $2 \mathrm{~A}$, belongs to the family of actinbinding proteins and mediates the Coro2A/actin-dependent mechanism of derepression of the inflammatory response genes [27].

We found no association between the development of $\mathrm{PE}$ and such canonical pathways as abnormal apoptosis and angiogenesis as described in several papers $[16,19$, $30,31]$. This is probably attributable to the interethnic variability of the gene expression profiles in the placental tissue due to the population differentiation of the regulatory regions of the genome, or due to the differ-

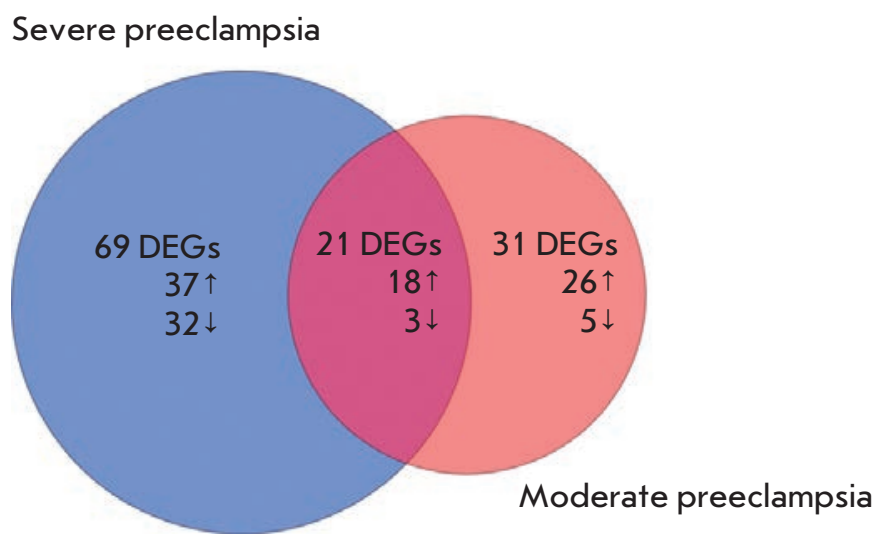

Fig. 5. Venn diagram showing the results of the gene expression profiling in moderate and severe preeclampsia and in physiological pregnancy. DEGs - genes that are differently expressed in females with preeclampsia and physiological pregnancy (control group). The arrow shows the increase $(\uparrow)$ or decrease $(\downarrow)$ in gene expression

ent criteria (population size, delivery time, severity of the disease, etc.) used in the formation of the examined groups. The different placental localization of the biopsy samples used in individual studies of the transcriptome in $\mathrm{PE}$ is another factor that apparently affects the occurrence of these contradictions. Thus, highthroughput sequencing (RNA-Seq) revealed significant differences in the gene expression profiles in the amnion, chorion, and decidua of the human placenta [32]. Similar findings were previously arrived at when performing a microarray analysis of the transcriptome patterns in different portions of the placenta [33].

Despite the aforementioned differences in the results of the DEG functional annotation, it remains of 
interest that changes in the expression levels of some DEGs identified in our work were also described in other studies (Table 5).

Thus, a significant increase in $L E P$ gene expression in preeclampsia was observed in almost all genomewide studies of gene expression profiles in the placental tissue. Leptin, the product of this gene, is one of the new serum markers of PE. It is known that leptin belongs to adipocyte-specific cytokines that regulate energy metabolism and are involved in various metabolic and neuroendocrine processes [39]. The studied group of $\mathrm{PE}$ patients did not differ significantly from the control group of patients in terms of weight and body mass index. None of the patients had abnormal weight gain during pregnancy, and therefore it can be assumed that the contribution of leptin to the development of $\mathrm{PE}$ is determined by other functions of this protein. Placental leptin is known to be involved in providing the flow of nutrients to the fetoplacental complex and to induce the trophoblast proliferation by inhibiting apoptosis $[40,41]$. Thus, an increase in the leptin level in the placenta may be a compensatory mechanism directed against endothelial dysfunction, which is observed in PE. Meanwhile, it was shown that leptin is involved in the activation of the sympathoadrenal system, which contributes to arterial hypertension, the main symptom of PE [42]. In addition, an important immunomodulatory function of leptin was found, which may also contribute to the development of pregnancy failure [43]. Despite the intensive studies devoted to LEP gene expression, only some works have focused on the analysis of the hereditary variability of this gene and its role in changing the transcription level and the structure of susceptibility to pregnancy failure. It was shown that carriers of the AA genotype of the rs2167270 locus (G19A) located in the promoter region of the LEP gene have elevated levels of expression of this gene in the blood, as well as the risk of PE and hypertension [44]. Association between another polymorphism (G2548A) localized at the LEP gene promoter with gestational diabetes [45] was found in the Czech population. Along with this, several studies [37, 46, 47] have revealed significant hypomethylation of this locus, as well as dysregulation of the placental epigenome during the development of $\mathrm{PE}$.

The increase in the expression of the long non-coding RNA 284 gene in the placental tissue of PE patients, which was observed in our work, is of particular interest in the context of the role of epigenetic dysregulation in the formation of this pathology. It has recently been shown that long ncRNAs perform vital regulatory functions in cells. In particular, it is assumed that they can function as a module scaffold in the specific, highly ordered organization of ribonucleoprotein complexes and induction of epigenetic changes in these loci. Some long ncRNAs can bind chromatin using remodeling enzymes and then participate in the local chromatin modification, e.g. in DNA methylation, by initiating or repressing transcription. This RNA class can participate in the binding of transcription factors and inhibiting gene expression [48].

The association between overexpression of the BAG3 and HSPA1A genes and the development of severe $\mathrm{PE}$ seems to be of interest. The protein product of the BAG3 gene is known to compete with Hip cochaperone for binding to the ATPase domain of the HSP70/HSC70 complex and thus inhibits the chaperone activity of the heat shock protein 70 (Hsp70), the product of the HSPA1A gene, whose expression is significantly elevated in severe PE (more than sixfold as compared to moderate $\mathrm{PE}$ and eightfold as compared to the control population). It is known that Hsp70 performs various functions. Improving the resistance of the protein biosynthesis apparatus to damaging influences and chaperone activity are the most significant of them. In addition, there is data indicating that Hsp70 participates in protein transport, conduction of the intracellular signal, and protease-dependent degradation [49]. It should be noted that according to the results of the functional annotation of DEGs, processing and presentation of peptide and polysaccharide antigens and chaperone-mediated protein folding are the principal processes characteristic of severe PE. Since the heat shock protein Hsp70 is capable of forming complexes with non-folded proteins and a wide variety of peptide fragments that are precursors of the antigenic peptides presented on the cell membrane along with other class I and II MHC molecules [50], it is reasonable to assume that the immunological control mechanisms of trophoblast invasion in the uterine wall and the immunological tolerance factors in the mother-fetus system play a key role in the pathogenesis of severe PE. The pathological effect of these factors can lead to gestational complications. Furthermore, many heat shock proteins exhibit immunoregulatory activity, stimulate the maturation of dendritic cells, and induce some proinflammatory cytokines [51]. These properties of these proteins may also contribute to the mechanisms of severe PE.

The statistically significant decrease in the expression of the APOC1 gene in severe PE, which was revealed in the present study, is probably due to the development of oxidative stress in the blood vessels of the placenta or the recently discovered immunosuppressive properties of the $\mathrm{C} 1$ apolipoprotein encoded by this gene [52]. It was previously shown that the serum of PE patients has a high level of triglyceride-rich lipoproteins, which can promote endothelial dysfunction [53, 
Table 5. Differentially expressed genes identified in this study whose association with preeclampsia has been previously shown in studies focused on the placental tissue transcriptome

\begin{tabular}{|c|c|c|c|c|c|c|}
\hline № & Gene & Gene product & $\mathrm{FC}$ & $\begin{array}{l}\text { Significance } \\
\text { level }\end{array}$ & Ethnic populations & Reference \\
\hline \multirow{8}{*}{1} & \multirow{8}{*}{$L E P$} & \multirow{8}{*}{ Leptin } & 10.94 & $<0.0001^{*}$ & Japanese & {$[30]$} \\
\hline & & & 8.58 & $0.036^{*}$ & Chinese & [34] \\
\hline & & & 40.11 & $1.35 \times 10^{-9}$ & Caucasian & {$[16]$} \\
\hline & & & 5.52 & 0.0020 & $\begin{array}{c}\text { Caucasian } \\
\text { Afro-American } \\
\text { Mongoloid } \\
\text { Spaniard }\end{array}$ & [18] \\
\hline & & & 108.9 & $<0.0001$ & Caucasian & {$[35]$} \\
\hline & & & 4.4 & $<0.0001$ & Korean & {$[36]$} \\
\hline & & & $\geq 1.5$ & $<0.05$ & Chinese & {$[37]$} \\
\hline & & & 11.79 & $<0.01 *$ & American & {$[38]$} \\
\hline \multirow{5}{*}{2} & \multirow{5}{*}{$B C L 6$} & \multirow{5}{*}{$\begin{array}{c}\text { Transcription factor - zinc finger } \\
\text { protein } 51\end{array}$} & 1.78 & 0.0154 & $\begin{array}{c}\text { Caucasian } \\
\text { Afro-American } \\
\text { Mongoloid } \\
\text { Spaniard }\end{array}$ & {$[18]$} \\
\hline & & & 2.02 & 0.0024 & Japanese & {$[30]$} \\
\hline & & & 2.24 & $3.58 \times 10^{-5}$ & Caucasian & {$[16]$} \\
\hline & & & 2.60 & $<0.01 *$ & American & {$[38]$} \\
\hline & & & $\geq 1.5$ & $<0.05$ & Chinese & {$[37]$} \\
\hline \multirow{5}{*}{3} & \multirow{5}{*}{ SIGLEC6 } & \multirow{5}{*}{$\begin{array}{l}\text { Immunoglobulin-like lectin } 6 \text {, which } \\
\text { binds to sialic acid }\end{array}$} & & $0.02 *$ & American & {$[31]$} \\
\hline & & & 2.13 & 0.001 & Caucasian & {$[16]$} \\
\hline & & & 2.73 & $<0.01^{*}$ & American & {$[38]$} \\
\hline & & & $\geq 1.5$ & $<0.05$ & Chinese & {$[37]$} \\
\hline & & & 4.5 & 0.019 & Caucasian & {$[35]$} \\
\hline \multirow{3}{*}{4} & \multirow{3}{*}{ RDH13 } & \multirow{3}{*}{ Retinol dehydrogenase 13} & - & $3.86 \times 10^{-8 *}$ & American & {$[31]$} \\
\hline & & & 1.91 & $<0.01^{*}$ & American & {$[38]$} \\
\hline & & & $\geq 1.5$ & $<0.05$ & Chinese & [37] \\
\hline \multirow{2}{*}{5} & \multirow{2}{*}{ NDRG1 } & \multirow{2}{*}{$\begin{array}{l}\text { Cytoplasmic protein belonging to the } \\
\text { hydrolase superfamily }\end{array}$} & 2.02 & 0.0001 & Japanese & {$[30]$} \\
\hline & & & 2.67 & $1.12 \times 10^{-5}$ & Caucasian & {$[16]$} \\
\hline \multirow{2}{*}{6} & \multirow{2}{*}{ BHLHE40 } & \multirow{2}{*}{$\begin{array}{l}\text { Transcription factor with helix-loop- } \\
\text { helix domain }\end{array}$} & 1.95 & 0.0004 & Japanese & {$[30]$} \\
\hline & & & 3.08 & $2.18 \times 10^{-5}$ & Caucasian & {$[16]$} \\
\hline \multirow{2}{*}{7} & \multirow{2}{*}{ KRT19 } & \multirow{2}{*}{ Keratin 19} & 1.75 & 0.0071 & Japanese & {$[30]$} \\
\hline & & & 2.28 & $1.59 \times 10^{-5}$ & Caucasian & [16] \\
\hline 8 & GPT2 & Alanine aminotransferase 2 & 2.45 & $3.70 \times 10^{-5}$ & Caucasian & {$[16]$} \\
\hline 9 & $P P P 1 R 12 C$ & $\begin{array}{l}\text { 12A regulatory subunit of phos- } \\
\text { phatase } 1\end{array}$ & - & $2.16 \times 10^{-8 *}$ & American & {$[31]$} \\
\hline 10 & CEBPA & CCAAT/enhancer-binding protein $\alpha$ & - & $2.52 \times 10^{-8 *}$ & American & {$[31]$} \\
\hline 11 & HK2 & Type 2 hexokinase & 3.90 & $3.87 \times 10^{-6}$ & Caucasian & {$[16]$} \\
\hline 12 & HMHA1 & Minor histocompatibility antigen HA1 & - & $1.23 \times 10^{-8 *}$ & American & {$[31]$} \\
\hline 13 & PVRL4 & Nectin 4 & 2.54 & $3.62 \times 10^{-5}$ & Caucasian & [16] \\
\hline 14 & $S A S H 1$ & $\begin{array}{l}\text { SAM- and SH3-domain-containing } \\
\text { protein } 1\end{array}$ & 2.54 & $1.22 \times 10^{-7}$ & Caucasian & {$[16]$} \\
\hline 15 & $S H 3 P X D 2 A$ & $\begin{array}{l}\text { SH3- and PX-domain-containing } \\
\text { protein } 2 \mathrm{~A}\end{array}$ & $\geq 1.5$ & $<0.05$ & Chinese & {$[37]$} \\
\hline 16 & SYDE1 & GTPase activating protein, homolog 1 & 1.55 & $<0.01^{*}$ & American & {$[38]$} \\
\hline
\end{tabular}

* Significance level including multiple testing correction. 
54]. Meanwhile, the blood level of E and A1 apolipoproteins is decreased in this pathology $[55,56]$. In addition, a protective role of the APOE $\varepsilon 2$ allele in the Kurd population was demonstrated, which is related to the high antioxidant properties of this allele according to the authors [57]. We failed to find any information about an association between $A P O C 1$ polymorphisms and gestational complications. However, it was shown that the insertion-deletion polymorphism at -317 position of the promoter region of this gene (rs11568822) is associated with Alzheimer's disease, while the rs4803770 marker is associated with the coronary heart disease [58, 59]. Since the APOC1 gene localizes in the same cluster as the $A P O E$ gene, it is assumed that these associations are due to the strong linkage disequilibrium between these genes [60]. However, we found no statistically significant changes in the expression level of the $A P O E$ gene. Therefore, it is reasonable to consider the APOC1 gene to be an "independent" new candidate gene for $\mathrm{PE}$. However, this assumption needs confirmation.

Thus, the findings indirectly confirm the immunological hypothesis of the development of severe PE, which postulates the key role of immune competent cells (B lymphocytes, monocytes, dendritic and NK cells) in the pathophysiology of this disease. This theory assumes that the etiopathogenesis of $\mathrm{PE}$ is triggered by insufficient trophoblast invasion into maternal spiral arteries, which is associated with a decreased expression of HLA antigens and "aggression" against NK cells. This results in reduced placental perfusion and development of hypoxia at the mother/fetus boundary, which, in turn, triggers the activity of pro-inflammatory cytokines, leading to endothelial dysfunction [61]. B cells may also contribute to the development of preeclampsia by producing anti-adrenoceptor antibodies.

\section{CONCLUSIONS}

The present work is the first Russian genome-wide study of differential gene expression in the placental tissues in normal and complicated pregnancies. The results indicate that some processes can play an important role in the molecular pathogenesis of PE: reactions associated with the immune response, cytoskeleton organization, cell-cell interactions, responses to various stimuli, and chaperone-mediated protein folding. Integration of the results of a functional annotation of DEGs, analysis of network interactions of the proteins encoded by these genes, and the study of the transcriptome of the placental tissue make it possible to identify a number of novel genes that could be associated with PE: LEP, SIGLEC6, BHLHE40, BCL6, RDH13, HSPH1, HSPA1A, BAG3, KRT19, RAC2, LIMCH1, BCL6 and LCP1.

We have also obtained evidence of a significant contribution of oxidative-stress-increasing expression of the genes of the Hsp70 and Hsp105 heat shock proteins, which are involved in the molecular mechanisms associated with impaired immune tolerance and initiation of the pro-inflammatory cascade, to the development of severe PE. Meanwhile, the observed increase in BAG3 gene expression is probably due to the compensatory mechanisms or anti-apoptotic properties of the protein encoded by this locus. This assumption is supported by a statistically significant increase in the expression of the Hsp70 and Hsp90 heat shock proteins, heat shock factor 1 (HSF1), and Bcl-2 anti-apoptotic factor in endothelial cells of the placenta of $\mathrm{PE}$ patients as compared to females with normotensive pregnancy [62]. Moreover, the analysis of the proteome of placental tissue from females with physiological and complicated pregnancies has revealed the significance of stress-inducible proteins, including Hsp70, in the pathogenesis of $\mathrm{PE}$ [63].

The findings may be useful for understanding the molecular mechanisms of PE and searching for new candidate genes and biomarkers for this pathology. In addition, they provide information for the development of targeted therapy for this disease.

This work was supported by the Federal Target Program "Scientific and Scientific-Pedagogical Personnel of Innovative Russia" (contract number 8118) and the Russian Foundation for Basic Research (grant № 14-04-01467).
REFERENCES

1. Marigorta U.M., Navarro A. // PLoS Genet. 2013. V. 9. № 6. P. e1003566.

2. Manolio T.A., Collins F.S., Cox N.J., Goldstein D.B., Hindorff L.A., Hunter D.J., McCarthy M.I., Ramos E.M., Cardon L.R., Chakravarti A., et al. // Nature. 2009. V. 461. № 7265. P. 747-753.

3. Saccone S.F., Rice J.P., Saccone N.L. // Genet Epidemiol. 2006. V. 30. № 6. P. 459-470.

4. Adzhubei I.A., Schmidt S., Peshkin L., Ramensky V.E., Gerasimova A., Bork P., Kondrashov A.S., Sunyaev S.R. // Nat. Methods. 2010. V. 7. № 4. P. 248-249.
5. Nicolae D.L., Gamazon E., Zhang W., Duan S., Dolan M.E., Cox N.J. // PLoS Genet. 2010. V. 6. № 4. P. e1000888.

6. Zhong H., Yang X., Kaplan L.M., Molony C., Schadt E.E. // Am. J. Hum. Genet. 2010. V. 86. № 4. P. 581-591.

7. Makarov O.V., Volkova E.V., Jokhadze L.S. // Russian Journal of obstetrician-gynecologist. 2012. № 1. P. 35-42.

8. Ailamazyan E.K., Mozgovay E.V. Preeclampsia: theory and practice. M.: MEDpress-Inform, 2008. 272 p.

9. George E.M., Granger J.P. // Expert Rev. Obstet. Gynecol. 2010. V. 5. № 5. P. 557-566.

10. Naljayan M.V., Karumanchi S.A. // Adv. Chronic. Kidney Dis. 2013. V. 20. № 3. P. 265-270. 
11. Scientific Center for Obstetrics, Gynecology and Perinatology of Kulakov, the Health Ministry of Russia, Institute for Family Health, The project "Mother and Child". Hypertension in pregnancy. Preeclampsia. Eclampsia. The clinical protocol. , 2012.51 p.

12. Smyth G.K. // Stat. Appl. Genet. Mol. Biol. 2004. V. 3. № 1. P. 1544-6115.

13. Ritchie M.E., Diyagama D., Neilson J., van Laar R., Dobrovic A., Holloway A., Smyth G.K. // BMC Bioinformatics. 2006. V. 7. P. e261.

14. Huang da W., Sherman B.T., Tan Q., Kir J., Liu D., Bryant D., Guo Y., Stephens R., Baseler M.W., Lane H.C., Lempicki R.A. // Nucl. Acids Res. 2007. V. 35. P. 169-175.

15. Szklarczyk D., Franceschini A., Kuhn M., Simonovic M., Roth A., Minguez P., Doerks T., Stark M., Muller J., Bork P., et al. // Nucl. Acids Res. 2011. V. 39. P. 561-568.

16. Sitras V., Paulssen R.H., Grønaas H., Leirvik J., Hanssen T.A., Vårtun A., Acharya G. // Placenta. 2009. V. 30. № 5. P. 424-433.

17. Nishizawa H., Pryor-Koishi K., Kato T., Kowa H., Kurahashi H., Udagawa Y. // Placenta. 2007. V. 28. № 5. P. 487-497.

18. Enquobahrie D.A., Meller M., Rice K., Psaty B.M., Siscovick D.S., Williams M.A. // Am. J. Obstet. Gynecol. 2008. V. 199. № 5. P. e1-11.

19. Founds S.A., Dorman J.S., Conley Y.P. // J. Obstet. Gynecol. Neonatal. Nurs. 2008. V. 37. № 2. P. 146-157.

20. Winn V.D., Gormley M., Paquet A.C., Kjaer-Sorensen K., Kramer A., Rumer K.K., Haimov-Kochman R., Yeh R.F., Overgaard M.T., Varki A., et al. // Endocrinology. 2009. V. 150. № 1. P. 452-462.

21. Lapaire O., Grill S., Lalevee S., Kolla V., Hösli I., Hahn S. // Fetal Diagn. Ther. 2012. V. 31. № 3. P. 147-153.

22. Rogue A., Lambert C., Spire C., Claude N., Guillouzo A. // Drug Metab. Dispos. 2012. V. 40. № 1. P. 151-158.

23. Hulse A.M., Cai J.J. // Genetics. 2013. V. 193. № 1. P. 95-108.

24. Benita Y., Kikuchi H., Smith A.D., Zhang M.Q., Chung D.C., Xavier R.J. // Nucl. Acids Res. 2009. V. 37. № 14. P. 4587-4602.

25. Lam K.K., Chiu P.C., Lee C.L., Pang R.T., Leung C.O., Koistinen H., Seppala M., Ho P.C., Yeung W.S. // J. Biol. Chem. 2011. V. 286. № 43. P. 37118-37127.

26. Nichol D., Christian M., Steel J.H., White R., Parker M.G. // J. Biol. Chem. 2006. V. 281. № 43. P. 32140-32147.

27. Huang W., Ghisletti S., Saijo K., Gandhi M., Aouadi M., Tesz G.J., Zhang D.X., Yao J., Czech M.P., Goode B.L., et al. // Nature. 2011. V. 470. № 7334. P. 414-418.

28. Gettemans J., van Impe K., Delanote V., Hubert T., Vandekerckhove J., De Corte V. // Traffic. 2005. V. 6. № 10 P. 847-857.

29. Percipalle P. // Nucleus. 2013. V. 4. № 1. P. 43-52.

30. Nishizawa H., Ota S., Suzuki M., Kato T., Sekiya T., Kurahashi H., Udagawa Y. // Reprod. Biol. Endocrinol. 2011. V. 2. № 9. P. 107.

31. Tsai S., Hardison N.E., James A.H., Motsinger-Reif A.A., Bischoff S.R., Thames B.H., Piedrahita J.A. // Placenta. 2011. V. 32. № 2. P. $175-182$.

32. Kim J., Zhao K., Jiang P., Lu Z.X., Wang J., Murray J.C., Xing Y. // BMC Genomics. 2012. V. 27. № 13. P. 115

33. Sood R., Zehnder J.L., Druzin M.L., Brown P.O. // Proc. Natl. Acad. Sci. USA. 2006. V. 103. № 14. P. 5478-5483.

34. Meng T., Chen H., Sun M., Wang H., Zhao G., Wang X. // OMICS. 2012. V. 16. № 6. P. 301-311.
35. Várkonyi T., Nagy B., Füle T., Tarca A.L., Karászi K., Schönléber J., Hupuczi P., Mihalik N., Kovalszky I., Rigó J. Jr., et al. // Placenta. 2011. V. 32. Suppl. S21. P. 9.

36. Lee G.S., Joe Y.S., Kim S.J., Shin J.C. // Arch. Gynecol. Obstet. 2010. V. 282. № 4. P. 363-369.

37. Xiang Y., Cheng Y., Li X., Li Q., Xu J., Zhang J., Liu Y., Xing Q., Wang L., He L., Zhao X. // PLoS One. 2013. V. 8. № 3. P. e59753.

38. Winn V.D., Gormley M., Fisher S.J. // Pregnancy Hypertens. 2011. V. 1. № 1. P. 100-108.

39. Denver R.J., Bonett R.M., Boorse G.C. // Neuroendocrinology. 2011. V. 94. № 1. P. 21-38.

40. Domali E., Messinis I.E. // J. Matern. Fetal. Neonatal. Med. 2002. V. 12. № 4. P. 222-230.

41. Laivuori H. // Front. Biosci. 2007. V. 12. P. 2372-2382.

42. Aizawa-Abe M. // J. Clin. Invest. 2000. V. 105. P. 1243-1252.

43. Fairfax B.P., Vannberg F.O., Radhakrishnan J. // Hum.

Mol. Genet. 2010. V. 19. № 4. P. 720-730.

44. Sugathadasa B.H., Tennekoon K.H., Karunanayake E.H.

// Hypertens. Pregnancy. 2010. V. 29. P. 366-374.

45. Vasku J., Dostalova Z., Kankova K. // J. Obstet. Gynec. 2008. V. 34. № 5. P. 858-864.

46. Jia R.Z., Zhang X., Hu P., Liu X.M., Hua X.D., Wang X., Ding H.J. // Int. J. Mol. Med. 2012. V. 30. № 1. P. 133-141.

47. Hogg K., Blair J.D., von Dadelszen P., Robinson W.P. //

Mol. Cell. Endocrinol. 2013. V. 367. № 1. P. 64-73.

48. Rinn J.L., Chang H.Y. // Annu. Rev. Biochem. 2012. V. 81. P. $145-166$.

49. Evdonin A.L, Medvedeva N.D. // Cytology. 2009. V. 51, № 2. P. 130-137.

50. Chernikov V.A., Gorohovets N.V., Savateeva L.V., Severin S.E. // Biomedical Chemistry. 2012. V.58. № 6. P. 651-661.

51. Abdulsid A., Hanretty K., Lyall F. // PLoS One. 2013. V. 8. № 1. P. e54540.

52. Cudaback E., Li X., Yang Y., Yoo T., Montine K.S., Craft

S., Montine T.J., Keene C.D. // J. Neuroinflammation. 2012. V. 10. № 9. P. 192.

53. Cekmen M.B., Erbagci A.B., Balat A., Duman C., Maral H., Ergen K., Ozden M., Balat O., Kuskay S. // Clin. Biochem. 2003. V. 36. № 7. P. 575-578.

54. Bayhan G., Koçyigit Y., Atamer A., Atamer Y., Akkus Z. // Gynecol. Endocrinol. 2005. V. 21. № 1. P. 1-6.

55. Koçyigit Y., Atamer Y., Atamer A., Tuzcu A., Akkus Z. // Gynecol. Endocrinol. 2004. V. 19. № 5. P. 267-273.

56. Catarino C., Rebelo I., Belo L., Rocha-Pereira P., Rocha S., Castro E.B., Patrício B., Quintanilha A., Santos-Silva A. // Acta Obstet. Gynecol. Scand. 2008. V. 87. № 6. P. 628-634.

57. Ahmadi R., Rahimi Z., Vaisi-Raygani A., Kiani A., Jalilian N., Rahimi Z. // Hypertens. Pregnancy. 2012. V. 31. № 4. P. 405-418.

58. Drigalenko E., Poduslo S., Elston R. // Neurology. 1998. V. 51. P. 131-135.

59. Ken-Dror G., Talmud P.J., Humphries S.E., Drenos F. // Mol. Med. 2010. V. 16. № 9. P. 389-399.

60. Lucatelli J.F., Barros A.C., Silva V.K., Machado Fda S., Constantin P.C., Dias A.A., Hutz M.H., de Andrade F.M. // Neurochem. Res. 2011. V. 36. № 8. P. 1533-1539.

61. Laresgoiti-Servitje E. // J. Leukoc. Biol. 2013. V. 94. № 2. P. 247-257.

62. Padmini E., Venkatraman U., Srinivasan L. // Toxicol. Mech. Methods. 2012. V. 22. № 5. P. 367-374.

63. Gharesi-Fard B., Zolghadri J., Kamali-Sarvestani E. //

Placenta. 2010. V. 31. № 2. P. 121-125. 